\title{
Byens kommunikation
}

\author{
SVEND ERIK LARSEN
}

\section{Sted i skred}

En af Karen Blixens fortællinger hedder „Samtale om Natten i København". Den handler om Christians VIIs eskapader i Københavns natteliv og især en halvberuset filosoferen over livet og dets uudgrundelighed i selskab med en af de letlevende damer. Det interesserer mig ikke her. Det gør titlen, og især titlens vigtigste ord: $i$. Både dette ord og hele titlen er så tilforladelig at den dårligt påkalder sig opmærksomhed. Den angiver tid og rum, klart, velafgrænset og entydigt, sammen med en aktivitet, samtalen, der samtidig lokaliserer mindst to subjekter, klarhjernede og ligeberettigede individer, i den københavnske nat. Der står jo samtale, ikke kommunikation, ikke meningsudvekśling, ikke information, ikke snak, ikke aflevering af beskeder, ikke aflæsning af tegn. Det er dannede individer der er på færde. Så det er godt at tid og rum ligger fast, ellers skulle de have brugt tid på at finde deres plads. Også passende at det er nat, så rummet omkring dem er en lysplet i en stor mørk hule, ikke større end deres stemmer og deres øjne rækker. Og uden om ligger jo det København de kender.

Men hvad nu hvis byens nat med det elektriske lys forvandles til „en totalt artificiel, unaturlig formverden. Et strålende og eventyrligt rum af svævende, stedløse, immaterielle lyspunkter og ellers mørke, som man umuligt kan applicere på almindelige naturoplevelser [...] Det elektriske lys nedbryder i byerne 'the solid form as the measuring unit of space'" (Nielsen 1968: 108)? Så løsnes de faste rammer for tid og rum. Selv om det er den genhemgribende elektrificering der for alvor sætter strøm til denne oplevelse (Nye 1992), er den ikke helt så ny. H.C. Andersen be- 
skriver i eventyret „Dryaden” (1867) sit møde med Verdensudstillingen i Paris og dens gaslys, og det samme gør den tyskie journalist Julius Rodenberg $i$ en artikelsamling med den sigende titel Paris bei.Sonnenschein und Lampenlicht (1867). Begge har det strålende gaslys som et gentaget motiv. Det gør byen overnaturlig, nat bliver til dag; og grænserne for tid og rum flytter sig på menneskets bud. Andersen fascineres af „Fortryllelsens Stad" og gaslysets „Sommersolskin” med fryd og gru - mest det sidste (Andersen 1899: 143, 147), mens Rodenberg mest måber imponeret over lyshavets trylleri, og mener at kunne opsummere hele verden ved at beskrive bare ét døgn i det parisiske "trylleslot" (Rodenberg (ed.) 1867: 37-52). Her er byen på vej væk fra at være noget man bare er $i$, hvor samtalende subjektive individualiteter befinder sig inden for givne rammer for tid og rum, bestemt primært af naturens døgnrytme og umiddelbart synlige fysiske grænser. Og dermed er byen selv i færd med at gå i opløsning som en klart afgrænset lokalitet med individualiserende træk. For hvad er „En samtale om natten i the Metropolitan Area of Greater New York"? Her har $i$ ingen mening som stedsangivelse, slet ikke når natten omkring de samtalende er et flimrende lyshav, og den konstante baggrundsstøj fra gade- og luftrum gør samtale til en eksklusiv og måske lidt antikveret karakteristik. Eller $i$ får en anden mening, for man kan jo godt cruise i the Los Angeles urban sprawl eller i de forskellige urbane segmenter af the New York, selv om man måske ikke kan være der. Peter Jukes kalder rammende sin kommenterede moderne byhistoriske tekst- og citatsamling for A Shout in the Street. Igen et $i$, der' bliver mere og mere flertydigt, $i$ byen angiver mere et sted i skred end en lokalitet på plads. Det er den proces vil jeg ridse op med byens kommunikation som omdrejningspunkt.

\section{Kommunikation med byen}

Kan man kommunikere med en by? Nogle har i al fald gjort det. "New York, New York, New York", synger Liza Minellli, „My city!" udbryder Walt Whitman. Andre sangere og andre byer er med: „Wien, Wien, nur du allein!”, crooner Ljuba Welitsch, „Kø- benhavn, du har alt hvad der drager mit Sind", lyder det fra Carl Brisson, „Paris! principe et fin ... Que fais-tu donc, Paris!” messer Alfred de Vigny sørgmodigt: Rækken kan fortsætte helt frem - eller ned - til Lundeborg-visen. Selve apostroferingen gør byen til en individuel entitet med sin egen afgrænsning og identitet, sit eget liv. En quasi-person. Det er den opfattelse der begynder at krakelere med den moderne storby, for hvem kan synge „Bay Area, you are my dreams"? eller „Le réseau urbain de Paris et ses arrondissements, tu es ma vie"? Nej, det kan kun fastholdes i turistreklamernes insisteren på at byer fortsat er individuelle steder.

Men reklamerne har jo stadig tag på den mekanisme der gør byer til steder, også selv om geografien og topografien ikke kan følge med længere - den retoriske eller diskursive konstruktion. Hvis byen skal være en quasi-organisme, vi kan kommunikere med, må den have sin egen livshistorie - et episk liv som en del af sin stedsbundne materialitet. Gennem en sådan historie kan byen kommunikere med sig selv ved at kommunikere gennem os der befolker og udfolder historien. I sin bog The Art of the City. Views and Versions of New York (1984) argumenterer Peter Conrad for at en by først får identitet når den har fået sin oprindelsesmyte, eller i det mindste en fortælling om sin begyndelse eller sin udvikling med fødsel, udvikling og formering og - måske - død eller genfødsel. Den monumentale ruinby er ikke den værste at henvende sig til, den kan i det mindste genopstå som monument over byen som det enestående og oprindelige sted. I sin ekstatiske besyngelse af New York udbryder Whitman i 1861: „I was asking for something specific and perfect for my city;/ Whereupon lo! upsprang the aboriginal name" som er det gamle indianske navn Mannahatta (Whitman 1969: 1954f). Og lo!, kunne vi sige, nu bliver byen ikke kun et objekt eller et sted, men et individuelt subjekt med en oprindelse og et navn. Når vi kommunikerer med og om byen, kan den kommunikere med sig selv. „Les rues parlent”, siger Balzac i Ferragus (1833), „Rosentaler Platz unterhält sich", siger Döblin i Berlin Alexander Platz (1928). I det ene tilfælde bliver byen en dæmonisk væsen, i det andet et maskineri på randen af sammenbrud. Og når vi kommunikerer 
med byen, bliver vi selv del af den: siger jeg $d u$ til byen, bliver jeg selv til et jeg $\mathrm{i}$ byen.

New York er et interessant grænsetilfælde for denne selvrefererende personificering og individualisering af byen som levende sted. Fra 1807 til 1811 udarbejdede og vedtog New Yorks bystyre - New York var da kun Manhattan, dengang en halvøden gitterstruktur for gadenettet vi kender i dag, the grid. Den omfattede hele Manhattan, skønt kun den sydlige tåspids var beboet (Homberger 1994) og resten var uvejsomt og ubeboeligt, hjemsted for bander. Planen havde intet med stedets særlige karakter at gøre eller med nogen særlige ideer om hvad en by er. Med de ensartede grundstørrelser, gadetyper og gadeforløb uden hensyn til terræn eller krav til beboelse, uden særlige æstetiske, trafikale eller hygiejniske forestillinger, skabte man først og fremmest en struktur for jordspekulanter, en pengemaskine, ikke engang en servicestruktur og slet ikke et livsrum. Ingen regnede alligevel med at der nogensinde kom så mange mennesker til halvøen, i hvert fald ikke i „de kommende århundreder", for det ville jo dreje sig om flere mennesker "end noget sted på denne side af Kina" (Ellis 1990: 202f). Alle sådanne fundamentale urbane hensyn hørte permanent fremtiden til, og man behøvede ikke at kere sig om livsbetingelser, en udvikling som genfindes i mange US byer (Glaab og Brown 1983).

Men samtidig med denne funktionalisme i kapitalistisk renkultur der afindividualiserer byen, kommer så i 1807 den første mytologiserende fortælling om New Yorks oprindelse, dens historie, dens grundlæggere, helte og skurke, dens mentalitet og overhovedet særligt udviklede identitet. Den fiktive forfatter Diedrich Knickerbocker - Washington Irving i forklædning - offentliggiorde A History of New York From the Beginning of the World to the End of the Dutch Dynasty, skrevet som et mock epic med et blink i.øjet. Men stadig henviser navnet på det eneste sande basketball hold i New York til denne forfatter: The New York Knickerbockers, kaldet The Knicks. Når holdet vinder bliver New York mere New York, kommunikerer med sig selv gennem the Knicks hvad enhver der følger NBA play offs kan forvisse sig om. Her brydes den stedløse moderne geografi - hvem er $i$ Manhattan? - med den stedsindividualiserende diskursive konstruktion - alle er $i$ Madison Square Garden, råbende.

Byens fortælling er en fortælling om et sted mennesker kan være i. Det kan eventuelt være et privilegeret sted, således at mennesker ved at være $i$ en sådan by samtidig er i hele verden. Byens fortælling kan gøre den til verdens centrum, således som det kendes fra fortællingerne om Jerusalem, Rom, London, Paris, New York osv. Og netop dermed angiver de grænsen for en sådan fortælling, for herigennem overskrider byen sig selv. Det er næsten mere end stedet kan bære.

Således hos Joachim Heinrich Campe, den tyske forlægger og forfatter fra Hamborg der besøger Paris i august 1789, revolutionens første jublende beruselse. Han står i Palais Royal, en blanding af markedsplads med boder, cafeer, spillebuler, ludere og butikker, et offentligt politisk frirum hvor revolutionens første brandtaler blev holdt. Paris er her i en social topografi en sekulariseret gentagelse af Jerusalem, der på middelalderens mappae mundi blev anbragt i universets centrum ifølge en kosmologisk og ikke en geografisk topografi (Ellul 1970, Whitfield 1994):

Denne have [...] bliver i mere end én henseende med rette kaldt la capitale de Paris og anset for ikke kun byens, men hele kongerigets midtpunkt. [...] Et menneske, der hele sin levetid aldrig har været uden for dette vidunderlige og magiske sted, ville alligevel kunne prale af ikke at stå tilbage for nogen som helst andre i verdens- og menneskekundskab eller i nydelse og fornøjelse af enhver art - undtagen nydelsen af naturen -, om de så havde rejst rundt på jordkuglens overflade i hele dens længde og bredde. [...] Så snart pariseren betræder dette sted, hører han op med at være franskmand; han bliver for en tid en fuldkommen republikaner, en verdensborger, der ikke længere kender til borgerlige og andre koinventionelle indskrænkninger og lænker. (Campe 1790: 72-74)

Byen er stedernes sted, den ydre verdens eller hele jordoverfladens centrum, men bliver da samtidig 'magisk' og dermed uvirkelig, ligesom de mennesker der hér finder en identitet ved at være i Paris, kun gør det ved atændre identitet hele tiden og kun bevare den for en tid. 
Hvad vi her ser drevet til det yderste, såvel i New York som i Paris omend på forskellig måde, er den klassiske opfattelse af sammenhængen mellem by og sted, hvis første diskursive konstruktion er Aristoteles' redegørelse for byen i hans bog om politik (Aristoteles 1921: kap. 7). Aristoteles skildrer byen, polis, som et fænomen med en bestemt identitet der har en fundamental kommunikativ og dermed social naturlighed: i byen går der en ubrudt linie fra en naturgiven menneskelig relation bestemt af kønnet, over familie og husholdning og til staten, dvs. polis og det opland den er centrum for, således at denne naturlighed gennemtrænger hele den urbane struktur. Byen er en selvberoende organisme af begrænset størrelse, hvor enhver borger - dvs. enhver fri mand samlet på agora - kunne overse dens sted, struktur og borgere og derigennem reflektere eller kontemplere over sig egen plads i byen og i kosmos. Selve kontinuiteten mellem natur og kultur holdes i live af denne kontemplation, som er det etiske formål med en by. Mennesket kommunikerer med sig selv i byen, når denne by lever op til sin ideale bestemmelse - samtaler om natten i Athen (Larsen 1993b).

Når Aristoteles skal redegøre for hvordan en sådan urban vision skal materialiseres, går han i detaljer om byens sted. Byens materielle struktur skal fremme den umiddelbare perception af byen som et specifikt afgrænset sted af menneskelig oprindelse, men med et højere formål og med en naturlig placering dér hvor den nu har sit sted. Den skal have en klar, men ikke for rigid gadestruktur. Hippodamus' grid er fint bare det ikke, som i New York, er over det hele. Der skal være en central plads og et højt beliggende tempel der kan ses på afstand som centrum. Og byen skal føje sig naturligt efter i landskabet: frugtbart opland byen kan leve af, forvarsmuligheder, vandforsyning, havn osv. Sådan et sted er ikke skabt, men fundet. Det har sin egen identitet som byen synliggør, så mennesket herigennem kan kontemplere over sit liv. Byen bygges i sit sted, ikke på et sted.

Vi er her dybt inde i Aristoteles' naturfilosofi om ting og deres rette sted, hvad enten disse ting er sten, byer eller mennesker. Den grundlæggende opfattelse er at der er en nødvendig sammenhæng mellem stedet $-\mathrm{i}$ videste forstand hele jorden - og de ting der er dér eller sker dér. Alle ting har et naturligt sted hvor de hører til og kan ses som det de virkelig er, og det er dér de er når de er i hvile. Hvile og bevægelse er de grundlæggende modsætninger i Aristoteles' fysik. Ét sted er udgangspunktet for at tingene kan bevæge sig eller folde sig rigtigt ud, i forhold til deres natur, og et andet sted er det rette sted for at de afslutter deres bevægelse igen. Slynger man en sten 10.000 gange op i luften, lærer den dog ikke at flyve, men falder tilbage til sit rette sted, siger Aristoteles (selv om Erasmus prøver at overbevise Moerlille om det modsatte). Der er steder hvis natur det er at give plads for dyrkning, andre der giver plads for en by, atter andre som - eventuelt samtidigt - giver plads for en kontemplativ nydelse af naturen. Det drejer sig om at definere sådanne steder, så man ved at man foretager sig det rigtige når man bruger dem.

Stedet har en ånd, genius loci, som ifølge den endnu ældre animistiske opfattelse beskytter stedet, en daimon. Senere opfattes stedets ånd som det naturgivne særpræg der gør en harmoni mellem menneske og natur mulig, giver dem en plads i forhold til hinanden. Det er denne tankegang som ligger bag den topologiske tradition i litteraturen helt op til de første moderne storbyer som London og Paris, der i litteraturens diskursive konstruktion bliver tvunget ind i den topologiske genre (Johnston 1984), eller som kan spores i de episke urbane grundlæggelsesmyter fra et par linier om Kä̈ i Genesis over Gilgamesh's, ÆEneas' og mange andres historier. Nogle steder holder man sig væk fra af naturlige grunde, andre bruger man; nogle bruger man til én ting, andre til en anden og atter andre til flere ting. Aristoteles bygger på en sådan opfattelse, når han beskriver hvad en by er, som et sted hvor mennesket kommunikerer med sig selv ved at være i byen og dermed finder sit eget rette sted. Da byen er den mest omfattende menneskelige praktiske og ideale bearbejdning af sted, er det klart byen er det privilegerede sted for en sådan kommunikation.

Det afgørende her er at der under alle omstændigheder er en nødvendig og ikke-vilkårlig forbindelse mellem stedet som materielt fænomen og dets funktion for mennesket. Det kan ændre sig lidt med teknologisk udvikling i landbrug, skovbrug, fiskeri, transport osv., som kan forbedre brugen og forståelsen af stedets 
iboende muligheder, men denne udvikling ophæver ikke den fundamentale ikke-vilkårlige forbindelse mellem stedet og brugen af det. Der kan være anvendelser i indbyrdes konflikt, men det skyldes at den ideelle overensstemmelse med stedets ånd ikke er fundet, eventuelt at den der har magt til at definere stedets ånd ikke gør det i forhold til stedets optimale muligheder, men kun i forhold til sine egne. En kritik heraf vil da orientere sig mod en fejlagtig anvendelse af stedet til det valgte formål. Når Augustinus skal begrunde Roms undergang, bygger han, naturligvis uden direkte referencer, på Aristoteles' argument for den . nødvendige sammenhæng mellem byen og dens sted. Det er den romerne bryder i et syndigt anfald af overmod ved at gå ud over grænserne for den rette by (Augustinus 1955). Megen kulturpessimistisk kritik af den moderne storby repeterer denne tankegang, med den ideale genius loci som skjult positivt modbillede: det moderne urbane kaos i byen og dets virkning uden for byen er menneskefjendsk i sin grænseløshed på alle planer. Det er et gennemgående træk i f.eks. Lewis Mumfords mange urban-historiske analyser, således i den monumentale The City in History (1961).

\section{Kommunikation gennem byen}

New York og Paris repræsenterer tidlige ændringer af byens kommunikation, hvor stedet fyldes med mere end det kan bære. Man kan selvfølgelig stadig kommunikere med byen og i byen, men kun ved at lukke øjnene for de ændringer der galopperende indrammer samtalerne. Den klassiske europæiske by frem til renæssancen og barokken planlægges efter en omfattende urban vision om stedet. Den kan være rent funktionel, som i en romersk militærforlægning, eller udtrykke byens ikoniske karakter, hvorefter byens lay-out som helhed imiterer naturens orden, således at volde, gader, bygninger osv. indordnes $i$ helheden, så byen kan blive en god by. Men New Yorks gadegitter, Paris' boulevarder, Wiens og Berlins fornyelser skal lette intern kommunikation og transport af ting, mennesker og kapital, eller slet og ret være et led i yderligere udvikling i en principielt endeløs proces. De er mere indekser for sociale behov end ikoner for kosmologiske visioner. Det er f.eks. klart udtrykt i det første større forsøg på en samlet både fysisk, social og æstetisk byplanlægning i USA, Daniel Burnhams plan for Chicago fra 1909. Chicago er anskuet som en moderne città ideale, men i modsætning til den klassiske europæiske by er den „uden skranker eller grænser” og er „den del af det ubegrænsede rum der nu optages af en befolkning som er i stand til uendelig ekspansion" (Burnham og Bennett 1970: 80).

Rummet er ikke den stabile ramme om kommunikationprocesser, men ændres i og med de finder sted, og kommunikationsprocesserne kan ikke kategoriseres som før med den kontemplative samtale på den ene side og andre typer på den anden. De bliver mangesidede og samtidige på mange planer og i mange medier. Vi bevæger os fra steder til stræder: den urbane rygrad bliver gaden, det kommunikative medium der bestemmer både rummets goplende dynamiske ændringer, samtalens forbindelse med andre urbane kommunikationsrelationer og den urbane kommunikation med det ikke-urbane territorium. Hvor før murens grænse bestemte denne kommunikative logik, er det nu gadens rum der er byens grænse - og gaden fører langt af led (Larsen 1992, Larsen og Petersen (eds.) 1996).

I sin artikel „The Street as a Communications Artefact" (Anderson (ed.) 1986: 207-211) bemærker Thomas Czarnowski indledningsvis at

byens afgørende egenskab - og en af forklaringerne på dens enorme vækst - er dens enestånde evne til at fungere som knudepunkt for regionale kommunikationsprocesser og til som en intern fysisk struktur at sørge for et let tilgængeligt netværk af kontakter og udvekslinger. [...] vi mener at bygaden som et enestående fysisk fænomen sørger. for kommunikationsprocesser af et omfang og en rækkevidde der er en vital betingelse for det sociale liv.

Gadehistorien er lang og kulturel forskelligartet som byhistorien selv (Anderson (ed.) 1986, Çelik (ed.) 1994, Hitzer 1971). Det afgørende vendepunkt er at gaden, som hos Czarnowski, gøres synonym med let tilgængelighed, ikke blot som et tomt og fromt ønske, men som et realistisk krav der hører byudviklingen $\mathrm{i}$ 
1800-tallets første halvdel til. Den engelske skribent Frances. Trollope illustrerer forholdet i sin kontrasterende beskrivelser af amerikanske byer og især Paris i bøgerne Domestic Manners of the Americans. (1832) og Paris and the Parisians in 1835 (1836). Hun nedsatte sig i 1828 som forretningsdrivende i Cincinnatti, men var ikke nogen økonomisk succes. Hun rejste en del og beskrev ubesmykket hvad hun kunne lide og ikke lide undervejs. De amerikanske byer roste hun generelt som åbne, rene og luftige og med gader der var bekvemme og sikre at færdes i. Paris, som hun besøgte efter hjemkomsten til Europa, fik helt andre prædikater: snavset, ildelugtende, ufremkommelig med gader der var farlige på grund af mørke, tømning af natpotter og suspekte personer.

Og den type kritik kunne nu omsættes og blev omsat i praksis. Den byudvikling der i Paris gjorde gaden til centrum, tog for alvor fart efter at Palais Royals træbygninger brændte i 1827. Det pulserende folkeliv, som havde fascineret Campe og som også Balzac når at opleve og gengive i Illusions perdues i kapitlet „Les Galeries-de-Bois" (Balzac 1966a: 473-476), flyttede andre steder hen: til gallerier og passager med butikker og cafeer, til de nye boulevarder og stormagasiner, til de nyanlagte gader og parker. Den amerikanske historiker Donald Olsen resumerer denne tendens i sin bog om London, Paris og Wien, The City as a Work of Art:

I sin kombination af gadens og parkens egenskaber lod boulevarden klogt gadeegenskaberne dominere. [...] Ved at føje den gamle parisiske gades sociale liv og tæthed til de oprindelige boulevarders grønne rummelighed, opnåede de nye boulevarder en helt ny urban form: den fuldendte gade, en konkret gengivelse af urbaniteten i sig selv. (Olsen 1986: 231)

Den amerikanske bysociolog Richard Sennett er så fascineret af de nye typer byrum, at han har omsat sine sociologiske studier til romanen Palais Royal. Her beskriver han konstruktionen af det nye Galerie d'Orléans. Det blev bygget efter Palais Royals brand på samme sted og foregriber den moderne storbygade som offentligt opholdsrum. Galleriernes urbane liv, med overdækkede indkøbsgader og slentrepromenader, er nærmest ledemotiv i
Walter Benjamins velkendte analyser af Paris som prototypisk moderne storby (bl.a. Benjamin 1980).

Senere bredes denne opfattelse af byen og dens liv ud over hele byen. I første omgang med noget så enkelt som ophøjede fortove med kantsten, hvor man kunne gå tørskoet og nyde selve det at gå, uden at skulle tænke på hvad man trådte i. Først fra slutningen af $1820^{\prime}$ erne tager denne byfornyelse rigtig fart. På samme tid indføres gaslys, og det gjorde gaderne sikre. Vold og tyveri har det sværere i fuld belysning. Man kan ikke blot se hvad der sker omkring én - se varer, ting og mennesker, men man kunne også selv blive set. Nye former for glasproduktion gjorde det muligt at lave store udstillingsvinduer. Med fortove og belysning kunne man gå frit og sikkert omkring, også uden for gallerierne. Gradvis gjorde kloakkerne også lortet usynligt og ulugteligt, og vandforsyningen nedsatte smitterisikoen - opfattelsen af hvad smitte er skifter i perioden - og dermed også angsten for at være tæt sammen med andre. Gaden blev i egentlig forstand et offentligt rum, et sted som alle byens forskelligartede mennesker havde uhindret adgang til, men derfor også stedet hvor man ikke kunne undgå at støde på de mindre behagelige sider af den eksplosivt voksende storby, og stedet hvor optøjer nemmere kunne finde sted.

Flanøren blev derfor hurtigt antaget for den typiske parisiske verdensborger. Ordet 'flanere' har, trods sine associationer til indbegrebet af mandlig parisisk elegance og raffinement, et germansk ord som sin rod: at strejfe omkring, cf. det negativt ladede danske ord 'en flane'. Jeg skal ikke her repetere de mange analyser af flanøren som urban prototype. Kun vil jeg tilføje at som alle mytologiske dannelser giver den et stærkt modificeret virkelighedsbillede. Flanørerne var i virkeligheden få og atypiske, og deres råderum var på størrelse med et frimærke i det centrale Paris omkring Madeleine-kirken (Larsen 1990b). Flanørerne var „dem . der aldrig har forladt Boulevard des Italiens' asfalt og for hvem Paris hørte op allerede ved kajerne, venstre bred" (Balzac 1965: 560, cf. Balzacs essay om boulevarderne i Diable 1845-46). Det skyldtes selvfølgelig at det krævede en solid tegnebog at føre et sådant liv. Men også at Paris i næsten et halvt århundrede var én 
stor byggeplads, med et grueligt rod som gjorde det svært at gå hvor man ville uden at få lakskoene plettet. Flanøren var mere en drøm, et håb om at den nye urbane virkelighed ville lave kaos og opbrud om til et sikkert og åbent livsrum for alle - med gaden som idealmodel - , et sted hvor hver enkelt kunne styre sine sanseindtryk, følelser og handlinger, mere et regressivt greb tilbage efter den stedsbundne by der er ved at forsvinde end et avantgardistisk moment. Nej, gaden og gadelivet, parker, cafeer, dansesteder og bynære udflugtsmål var i virkeligheden først og fremmest for den voksende nye og mere anonyme klasse af funktionærer, les employés, med reguleret arbejdstid og især reguleret fritid. Det var dem der faktisk brugte den nye by fuldt ud. Og det er ofte dem der karikeres i de talrige skildringer af gadeliv, som f.eks. Victor Fournels Ce qu'on voit dans les rues de Paris (1858) eller Charles Dickens' Sketches by Boz (1835).

Men den nervøse gadeoplevelse bliver en central æstetisk kategori, der kan spores fra de tidligste skildringer af byen til i dag, fra Baggesen til Bellow. I Labyrinten (1793) møder vi Jens og hans ven der "gaar lige op til [domkirken i Strasbourg] uden at standses i vor andægtige færd af de lokkende Placater, Vertshuus, Caffehuus- og Boghandlings-Skildter". Helt andægtige kan de nu ikke være, når de så detaljeret gør rede for det de slet ikke standses af. Der er en dobbelt bevidsthed på færde, mellem koncentration og sansestyret distraktion, som til slut efter en svimlende tur op i domkirke tårnet bliver til regulær jeg-spaltning: „Jeg saae op til Spiirspidsen, og saae mig der endnu. Saaledes ravede jeg til Vertshuset" (Baggesen 1965: 288, 302). I Bellow's Herzog (1964) prøver den neurotiske Moses Herzog at modstå sansebombardementet. Her er han i en taxa, og „følte han selv var del af det hele - i værelserne, i butikkerne, kældrene - og på samme tid mærkede han faren ved disse mangedoblede pirringer. Men han ville blive OK. Han var overstimuleret; han måtte berolige disse overspændte galopperende nerver" (Bellow 1964: 38). Også en dobbelt og konfliktbetonet bevidsthed. Der er en afsluttende viljesytring der holder det psykiske kaos på plads, men på den anden side er det mere en besværgende afværgereaktion end en faktisk realitet, mere angst end beslutsomhed (han 'ville' og han 'måtte').
Samme oplevelser som den andægtige og målrettede Baggesen der dog lader sig distrahere, kun mere desperat og accentueret. Skønt byen med gaden som centrum fortsat opfattes som et rum, er det et rum som ramme om permanent forandring, både af rummet selv og af de subjekter der lever og oplever det. Der er lysårs afstand til den kontemplative ro Aristoteles gør til byens ideal og centrale bevidsthedsform, hvor stedet og mennesket forenes i deres fælles bestemmelse. Den moderne storby er mere en kommunikationskanal end et sted.

I denne sammenhæng er kommunikation, for at vende tilbage til Thomas Czarnowski, ,enhver udbredelse eller udveksling af personer, varer, budskaber eller energi, hvordan de end bliver overført, skrevet eller transporteret" (Anderson (ed.) 1986: 207). I denne brede henseende gør fire kommunikative kategorier sig gældende i gaden:

1) Kommunikation der forudsætter kommunikationsparternes kropslige tilstedeværelse og bygger på kropsbundne kommunikative kompetencer: bevægelse, lugt, berøring, råben, gestik, talesprog osv. Det var netop denne kategori som fik øget betydning med den tidlige moderne bys nye elementer: fortove, belysning, cafeer, bykort beregnet for fodgængere, udstillingsvinduer osv., altsammen ting der både forudsatte og konsoliderede gaden som et åbent og sikkert sted for alle.

2) Kommunikation som udvider den kropsbaserede kommunikation: brugen af skilte med skriftsprog og piktogrammer, der reklamerer eller giver andre oplysininger som fơr hørte til en vægter eller udråber, og oplyser om selve gaden med navne og husnumre, hvad enten det sker i gaden eller om gaden i vejvisere og telefonbøger; også køretøjer og transportmidler af enhver art: cykler, vogne, biler, ledninger, rør, kabler osv.

3) Kommunikation der består i flytning og udveksling af varer: vand, strøm, fødevarer, elektroniske budskaber og alle øvrige varer som transporteres gennem gaderne.

4) Kommunikation der har form af transport af biprodukter fra de første tre typer kommunikationsprocesser: affald, bortkastet papir og emballage, energitab, forurening fra biler, kloakslam osv. 
Gaden bliver generalmetafor for alle former for kommunikation Victor Hugo beskriver således de nye kloakker som en analog dannnelse i forhold Paris gader, både i struktur, udseende og funktion (Hugo 1973: III, bog 2). I modsætning til 60'ernes nostalgiske urbane metafor for den stedsbundne by, the global village, har udtryk som the electronic highway, the infobahn o.l. den moderne bygade som skjult reference, ikke byen som afgrænset sted. Det gælder også begrebet den 'analoge by' (i Sorkin (ed.) 1992) om netværk af fodgængerbroer og -korridorer. I den stedsbundne bykonception, er konstruktion, vækst og fremskridt den urbane forandrings grundlæggende logik, men destruktion, affald, spild er afvigelser som må forhindres. I modsæetning hertil gør Czarnowkis kommunikative indfaldsvinkel til den moderne by såvel konstruktion som destruktion, såvel udveksling af varer og budskaber som produktion og transport af affald og spild til lige så aktive og afgørende processer i byens liv og udvikling. Byens liv og udvikling kan ikke længere anskues som en lineær proces: fra oprindelse via udvikling og organisk vækst mod klimaks og måske stilstand eller forfald. En byhistoriker som Spiro Kostof har derfor den 'urbane proces' og ikke den urbane struktur som grundkategori: aldrig så snart er bygmestrene færdige, før menneskeligt slid, vejr- og vinderosion, de små uregerlige forandringer bliver lige så fundamentale elementer i byen (Kostof 1992: kap. 5). Og en filosof som Anne Cauquelin understreger at det er mere relevant at se byen under tidens end under rummets synsvinkel: den er mere en materiel proces af lige dele nedbrydning og opbygning, end et bebygget rum, mere proces end sted (Cauquelin 1986). Byens identitet er denne form for forandring, ikke dens særlige måde at tilhøre eller optage en bestemt lokalitet.

Men i og med Czarnowski tager gaden og dermed et rumligt fænomen som udgangspunkt, tvinger han os dog til fortsat at anskue kommunikationsprocesser i forhold til det rum de foregår i, og ikke kun i forhold til kommunikationens indhold eller agenter. Gaden bliver en spatial model for den urbane kommunikation overhovedet, dvs. den udtrykker det urbane rums former og funktionsbetingelser. „Fysisk [dvs. spatialt] kan byen betragtes som et uhyre konglomerat af kommunikative artefakter" (Anderson (ed.) 1986: 208). Når de fire kommunikative kategorier får liv i byen, er de primært flettet sammen på rumlige betingelser.

Czarnowski opregner tre sådanne rumlige betingelser for byens faktiske kommunikation:

1) Kommunikationen er bestemt af den måde hvorpå genstande og agenter har adgang til kommunikationsrummet, idet forskellen mellem privat og offentlig udgør den grundlæggende betingelse.

2) Kommunikationen er yderligere bestemt af hvordan objekter og agenter optager rummet eller placeres i rummet, idet forskellen mellem på den ene side det personlig rum, med udgangspunkt i den individuelle kropsoplevelse (intimitetsafstande, spontan tiltrækning og frastødning o.l.), og på den anden side det sociale territorium, som drejer sig om institutionalisering af forholdet mellem min og andres position, hvad enten det sker som høflighedskonvention („er den plads ledig?“) eller på juridisk grundlag (,samtale med chaufføren forbudt under kørslen").

3) Endelig er kommunikation betinget af regler for passage gennem rummet, kodificeret i færdselslove, adskillelse af fortov fra kørebaner, adgang-forbudt skilte o.l.

For Czarnowski angiver gadens tre spatiale kommunikationsbetingelser - tilgængelighed, positionering, passage - almene betingelser for urban kommunikation overhovedet: „I et videre perspektiv er det klart at sådanne generelle kommunikationsmønstre for menneskelig organisationsformer gælder urbane artefakter hinsides den umiddelbare kontekst gaden udgør" (ib.: 209). Til dette videre perspektiv hører også atændringer af de tre betingelser vil betyde historiske forskydninger for de urbane kommunikationsformer og -medier som helhed. Czarnowski hævder således at

Gadens relativt afgørende funktion som det sted disse kommunikationsmønstre folder sig ud, har ændret sig, og den generelle historiske udvikling har faktisk været at gaden gradvis er kommet til at spille en mindre rolle i forhold til de artefakter som manifesterer disse mønstre. 
Det betyder ikke at gaden bliver brugt mindre [...], men snarere at den bliver brugt til mindre. (ib.: 209).

Den umiddelbare konsekvens er at de rumlige betingelser for den urbane kommunikation i almindelighed bliver mindre afgørende. Czarnowski anfører tre grunde til denne udvikling:

1) Kommunikationsteknologi gør rækkevidden af menneskets lingvistiske og andre semiotiske kompetencer mindre og mindre stedsbundet.

2) Transportmidler gør overførsel af varer mere og mere uafhængig af kroppens særlige bevægelighed, som f.eks. det at gå, lære at køre bil, løfteteknikker osv.

3) Gadenettet udformes i forhold til disse to ændringer og ændrer således vægtfordelingen mellem de fire kategorier: enten adskilles de som fire adskilte rumlige funktioner i fortsættelse af den funktionalistiske byplanlægning, eller, hvis de realiseres i samme rum, får de kropsbundne og dermed stedsbundne mindre betydning for rummet og kommunikationen som helhed $\mathrm{i}$ forhold til de øvrige. De nye gader hvor fodgængere i 1800-tallets første halvdel kunne begynde at opfattehele byen og dens mangfoldighed bare ved at gå, er blevet til specialiserede transport- og konsumkorridorer. Kommunikationen ved hjxlp af byen bliver vigtigere end kommunikationen med, $i$ og gennem byen

\section{Kommunikation ved hjælp af byen}

Det er næsten blevet til en kliche at byens fysiske og kulturelle udvikling svarer til en stigende stedløshed. Og da byen er den fundamentale kulturelle dynamo i store dele af verden, så følger denne stedløshed med som en skygge til byens øvrige manifestationer. Vi lider af „placelessness“ signalerer Edward Relph i Place and Placelessness (1974), og Yi-Fu Tuan maner i bl.a. Space and Place (1977) til besindelse på vegne af den tabte stedsbevidsthed så vi kan genfinde genius loci, sekunderet af Christian NorbergSchultz i Genius Loci (1984). Sociologerne Hartmut Häußermann og Walter Siebel kritiserer også i Neue Urbanität (1985) at den moderne by er blevet „,entraümlicht“, men tænker mindre på tab af sansen for stedet i almindelighed, og mere på tabet af funktionelle og betydningsfulde offentlige rum. I en mere utvetydig glæde over den fornyede vægtløshed ser Michael Sorkin for sig "dannelsen af en helt ny form for by, en by der ikke er knyttet noget sted til“" (Sorkin (ed.) 1992: xi). Han suppleres energisk af computer-zombien William Mitchell, der i City of Bits (1995) gør alle, og ikke kun nogle, rumlige og stedslige kategorier til kommunikative funktionskategorier (adgang til medier, kodning, loops osv.) og derpå reducerer ethvert rumligt fænomen til et vedhæng til de globale elektroniske netværk. Byen er kun et tilfældigt knudepunkt for netværkene, et medium ved hjælp af hvilket vi der bruger mediet kommunikerer med alt muligt andet og alle mulige andre.

Lad os lige spise brød til. Vi bliver jo stadig kørt over af biler, har sex med nogen bestemte steder, venter på bussen ved stoppestedet og laver vrøvl hvis vi ikke kan finde ting de steder de skal være. Og selv harddisken i min computer skal sidde et sted og være tilsluttet nettet bestemte steder. Hvad vi er vidne til, og deltager $i$, er snarere en ny type stedsbestemmelse og stedsbevidsthed. Et par eksempler inden vi beskriver den.

Hans-Jørgen Nielsen bjergtages af New York

i selvsamme øjeblik jeg drejer ned ad gaden og ser aftensolen komme væltende vestfra ad tværgaderne og højere oppe direkte mellem tinderne; så alle facader bliver et dramatisk spil mellem flydende rødgyldent og skygge. [...] En naturoplevelse af den art der med ét hug skiller kroppen fra tid og tyngde. Man runder et hjørne og drejer uformodet ind i et syn, der ændrer alt. Den gyldne by. Kroppen flyder, og tankerne opholder sig udelukkende, hvor dén er. Myterne tegneserierne, filmene er kommet til virkelighed. Naturoplevelser er virkelig det nærmeste ord. (Nielsen 1985: 35)

Jeg'et oplever ikke naturen, men har en naturoplevelse der gør det umuligt at skelne mellem kulturens og naturens rette sted, mellem fiktionens og virkelighedens sande sted. Og han får oplevelsen på vej i fuld fart gennem gaden. Han træder ikke i forbindelse med naturen i byen, eller gennem byens gader ud på landet. Ved hjælp af byen bliver oplevelsen af den til natur og 
den er dermed det samme som natur. Den naturgivne skelnen mellem byens og naturens sted er gået fløjten.

Mytologiseringen bliver, som man kan se hos Nielsen, en virkelig del af et sådant sted, ikke systematisk som en omfattende historie eller et allegorisk-religiøst fortolkningssystem, men som en erindring med associativ oprindelse, til stede når den bruges og derpå væk igen. I John Dos Passos Century's Ebb (1975) suser vi mod New York:

Trafikken suges på et øjeblik ned under jorden til Lincoln tunnellens rolige rutine, uendelig som kontorarbejde, fliseklædt som de badeværelser der annonceres for ved landevejens moteller ... det ensartede lys glider over i brutalt solskin. Betjente. New York. (Dos Passos 1975: 18)

En kort sekvens struktureret som en døds- og genfødselsfortælling, styret af uimodståelige kræfter, igen erfaret undervejs på gadens kommunikationsnet. Og selv når referencerne, som hos f.eks. Walter Benjamin i skitsen „Tiergàrten” fra Berliner Kindheit um neunzehnhundert, er helt eksplicitte med hentydninger til Ariadne, labyrinter og hydraer, får de ikke deres prægnans ved 'korrekt' brug, men af deres funktion i den givne erfaringssammenhæng, hvor de kan blandes med og bliver samtidige med andre spredte kulturreferencer som til Aragons Le Paysan de Paris eller klassicistiske arkitekturelementer. Det er ved hjælp af byen at personerne kommunikerer med myterne, og at erfaringen og ikke byen bliver mytologiseret.

Der er ingen referencer til en grundlæggende naturlig rumafgrænsning hvorpå andre stedsbestemmelser hviler, natur vs by, eller til en fast mytologisk eller ideologisk fortolkningsramme for den rigtige by. Også samtale og sanseperception, igen moduleret af gadens trafikstrøm eller transportens bevægelse, bliver da arbitrær i forhold til rum og personer. Allerede Balzac bemærker om M. Crevel, da han i begyndelsen af La cousine Bette (1845) kører gennem Paris' gader, at man „udsender opmærksomme blikke der er bestemt for fjerne smukke øjne, men som tilfældigvis opfattes af andre" (Balzac 1966b: 10). Og små hundrede år senere skildrer Dos Passos i U.S.A. (1930-36) Dick undervejs gen- nem Frankrig. Han „kørte en Ford for sig selv og havde så travlt med at huske hvad han skulle gøre med sine fødder at han næppe bemærkede landskabet" (Dos Passos 1979: II, 202). I William Gibson Neuromancér (1984) forløber en samtale således: "',På venstre side", sagde Mercedes-bilen, mens den styrede gennem en labyrint af regnfulde gader, „er Kapali Carsi, den store bazar". Ved siden af Case frembragte finnen en anerkende lyd, men han så i den forkerte retning" (Gibson 1993: 110f). Personer hverken kommunikerer med hinanden eller med en bestemt omverden eller følger en vej mod et sted. Ved hjælp af byens og dens rumlige forlængelse oplever de blot at de er til stede, uden helt at vide hvor og med hvem. Snak og perception er tilstedeværelsesmarkører.

Denne ubestemmelighed giver byen en stedløs skæbnekarakter, som hos Paul Auster i The New York Trilooy. Hovedpersonen Quinn spekulerer over sammenhængen mellem skæbne og ordet "det":

Det var noget ligesom ordet “det" i sætningen „det regner" eller „, det er nat". Hvad det "det" henviste til havde Quinn aldrig vidst. Måske en generaliseret betingelse for tingene som de var; det forhold at noget bare er, det grundlag hvorpå denne verdens begivenheder fandt sted. (Auster 1990: 133)

Disse hurtige eksempler på manifestationer af det der er blevet kaldt stedløshed viser nogle klassiske kultur- og kommunikationsskabende rumlige kategoriseringer i hvert fald ikke er som de har været, og at de er uløseligt forbundet med gaden, dens kommunikationsformer og -midler. Og de viser også at disse vilkår ikke opfattes som særligt negative eller tragiske, men som en relativt neutral fakticitet, ja i nogle tilfælde som opløftende. Det er en anden stedsoplevelse, ikke fravær af stedsoplevelse. I hvert fald fire ændringer i forhold til tidligere kan vi påpege, alle dele af byens ændringer:

1) Kun få lokaliteter er defineret ud fra én fundamental funktion, som fodgængerområde, kørsel, hvile, køb og salg, parkering, osv. De fleste har flere funktioner, og selv hvis de har en fun- 
damental funktion, ved alle at den temporært eller permanen kan ændres, når byen ændrer sig eller når vi beslutter det. Mange, men selvfølgelig ikke alle funktioner, kan finde sted efter tur eller samtidigt. Det særlige ved de offentligt rum er ikke deres institutionaliserede offentlighed, men deres multifunktionalitet (se Brill 1989).

2) Ingen historisk reference kan defineres hvad et sted virkeligt er. Kirker sekulariseres, ældre bygningers og pladsers historie er mere historien om turistkontorernes funktionelle monumentalisering af stederne end stedernes funktionelle historie (se Krier 1978).

3) Æendringer af byens fysiske rum sker inden for en enkelt generations umiddelbare erfaring og erindring, ofte flere gange. Byen ser ikke bare ud som den gør, men ser ud som den gør indtil den ser anderledes ud.

4) Næsten enhver kommunikationsproces kan realiseres med samme resultat og effektivitet på mange steder og med mange medier: man kan ordne sager med banken med telefon, fax, personligt fremmøde, e-mail, gå gennem forskellige medarbejdere osv. Der er meget få kommunikationsformer der hører ét og kun ét sted til og kræver ét og kun ét kommunikationsmedium. Men vi har jo en række kropsbundne kommunikationsformer der ikke sådan lader sig erstatte, og som der endog knytter sig en del lyst til. Det er derfor ikke mærkeligt at eksemplerne ovenfor lægger vægt på erfaringen af kropslig tilstedeværelse som stedsbestemmelse, mere end på andre momenter som fysiske særtræk, andre særlige subjekter, særlige kommunikationsformer, særlige historisk bundne erindringer, genkendelighed, praktiske hensyn osv.

De klassiske rumkonstituenter er ikke væk, men er permanent genstand for en redefinition på situationsbestemte betingelser, der ikke nødvendigvis er rumlige men er knyttet til bevægelige tilstedeværelseserfaringer. Hvis de er kollektive, er de det kun hvis de defineres sådan i situationen, eventuelt, som hos Nielsen eller Benjamin, med henvisning til naturen eller til mytologiserende fortællinger (Larsen 1991c).
Czarnowskis tre betingelser for spatial kommunikation, kanaliseret $i$ eller modelleret over gadens urbane rum, ændrer sig derfor, således om han antydede:

1) Når bestemte steder i høj grad mister deres privilegerede status, bliver sikkerhed og kontrol vigtigere end adgang. (se Sorkins bidrag i Sorkin (ed.) 1992, Francis 1989).

2) Positionering på et sted bliver ikke en måde at opholde sig dér, men forudsætning for bevægelse mellem steder (Larsen 1994a, 1996a).

3) Passage gennem rum reduceres til fordel for rådighed over kombination af netværk:

På disse betingelser bliver byen et medium for substitution af steder. En moderne anonym agora, hvor offentlighed ækvivalerer fælles muligheder på individuelle betingelser, og hvor omfanget af kommunikationsmuligheder er vigtigere end stedfunden kommunikation. Magtproblemet får en ny accent og bliver mere relateret til information og kommunikation end til territorier. Rum er ikke en 'beholder' hvori livet leves og som skal erobres, noget man er anbragt $i$ og eventuelt ændrer som i byen bag voldene eller i gaden. Spørgsmålet om hvad byen eller den urbant bestemte omverden $e r$, rejses slet ikke, kun hvordan den opfattes eller opleves. Og den opleves ikke kontemplativt eller funktionelt, ikke et 'nu er jeg hvor jeg skal være'; ikke et 'her kan jeg gøre det eller hint' eller 'her kan jeg kommunikere med noget eller nogen'. Snarere er oplevelsen transitionel: 'her kan jeg bevæge mig derhen'. 'Her' betyder altid 'herfra'. Appellen til de kropsafhængige og individuelt styrede rumafgrænsninger og funktioner er stærkere end alle andre spatiale betingelser.

Er det nu en rent æstetiserende oplevelsesmodus, der eventuelt kan beskrives psykologisk og fænomenologisk (se Larsen 1990a, 1993a, 1994d, Larsen og Johansen 1994: kap. 6)? Har det overhovedet noget med by at gøre? eller er det bare en af de vanlige spekulative postmoderne abstraktioner? Hvis man bevæger sig fra New York under Hudson River til New Jersey til Bridgewater, kan vi antyde et svar. At sige hvor Bridgewater ligger er svært som en almindelig stedsangivelse, f.eks. i forhold til en an- 
den by som man skulle kunne se den, sådan med byskilte, hovedgade, kirke, skole osv. Den er heller ikke centrumløs som så mange amerikanske byer. Man kan ikke få øje på den efter de kriterier. Det mest præcise er at sige den ligger hvor US highway $202,206,22$, innerstate road 28 og interstate highway 287 møder hinanden. Disse veje er på ingen măde varianter af eller forlængelser af bygader, som Czarnowski har diskuteret som kommunikationskanaler, for de fører ingen steder hen i forhold til Bridgewater, hverken til, fra eller gennem. Den er bare dér hvor de skærer hinanden. Og det just det der gør den til en særlig by, en variant af den ny type der er kaldt edge city (Gareau 1991). Det er hverken en parcelhusforstad eller en soveby for enden af S-banen. Det er et knudepunkt for kommunikationskanaler. I dette tilfælde hovedveje der fører til andre knudepunkter: lufthavne, banegårde, nærliggende metropoler.

Hvad kan man se dér? Ja, udover vejene ser man lidt rester af ensomt beliggende småhuse, et par moteller og benzinstationer, skilte til nærliggende småbyer. Og flotte administrative hovedkvarterer for store firmaer. I Bridgewater var der i 1993, da jeg boede på et af smånnotellerne et par måneder, bl.a. IBM, Hoechst, Johnsons, Chemical Bank, Olivetti. Så man kan også regne ud at der er elektroniskenetværk udover de andre. De primære urbane funktioner på stedet er administration og servicevirksomheder. Først lægges store virksomheders administrative hovedkvarterer derud, med gode pendlemuligheder mellem hjem og arbejde og ud i den store verden for de ansatte. Dernæst eller samtidig med kommer der indkøbscentre o.l., ikke for beboerne, for der er ingen, men for et opland langs vejnettet. Og så måske lidt beboelse i velanlagte villakvarterer. Det primære er imidlertid at stedet overhovedet ingen tiltrækning eller særpræg har, udover at det er nemt at komme til og fra og derfor er det billigere at bo og bygge dér end i en „rigtig“ by. Edge Cities er derfor højst ustabile urbane former, mere ustabile end forstæder idet både personer og funktioner er ustabile. Det eneste der ikke er plads til, er primær produktion med brug af naturressourcer, hvad enten det er landbrug eller industri. Heller ingen affald eller forpligtelse på en samlet landskabsforvaltning melder sig. Sådanne fænomener ligger en biltur, en flyrejse eller en elektronisk postgang borte. Edge City behøver derfor heller ikke, som de tidlige storbyer, systematisk at anlægge naturscenerier i parker og grønne områder som aktive modbilleder til produktiv naturudnyttelse, eller lave gode bymiljøer for den urbane kommunikation (måske et par jogging-stier o.l. hvis lidt solskin skulle kunne trække de ansatte væk fra firmaets fitness rum). Bridgewater er administrativt set et township med en driftig borgmester der så på sit territorium ikke som et mere eller mindre attraktivt sted, men som et knudepunkt. Vejene var der, skulle måske rettes lidt til. Men der manglede en shoppingmall. Den byggede han som om den havde et befolkningsunderlag på Århus' størrelse. Så skulle firmaerne og pendlerne komme af sig selv. Og det gjorde de. Og de gror ikke fast som Lego eller Danfoss, for de producerer ikke en pind, men styrer en produktion 117 andre steder. Stedet er primært defineret ud fra hvad man kan slippe for at have på stedet, den permanente transitlogik. En gentagelse af gaderummets oplevelsesindividualisme på et abstrakt systemniveau: stedet er kun i det billede af det hvorigennem jeg oplever det.

Netop derfor melder sig også her den samme kropsnærhed som den irreducible men situationsbestemte stedskonstituerende faktor, akkurat som i de litterære citater ovenfor. På Joel Gareaus spørgsmål om hvorfor man overhovedet flytter hovedkvarter, ja overhovedet bygger det med velplejede plæner og behagelig beliggenhed, når de elektroniske netværk ikke er æstetisk og socialt følsomme? Hvorfor bygge byer, selv så barberede byer som Edge Cities? Svaret er

Ser De, det er spørgsmålet om fremtiden. Hvorfor bliver folk ikke bare hjemme og arbejder? Vi har over 1000 ansatte her og mindst 10\% arbejder hjemme via vores netværk. Særlig kvinder på barselsorlov vil gøre meget af deres arbejde hjemme på deres PCer. Men der er en grænse for hvor langt det faktisk fungerer. Selvfølgelig er det forskelligt for forskellige mennesker, men man mister gruppefølelsen, evnen til at samarbejde, hvis man ikke mødes direkte, ansigt til ansigt. Man kan sidde hjemme en del af tiden, og om aftenen og i weekenden. Men de bliver nødt til at møde her, ellers taber man drivkraft som fællesskab. (Gareau 1.991: 37) 
Så det lejlighedsvise, midlertidige træf er ikke nødvendigvis blot et symptom på at stedløshed, mangel på tilhørsforhold eller kulturel hjemløshed, således som de mange kritiske analyser af den moderne storby vil vide, men en måde gennem sin tilstedeværelse at bekræfte at vi alle hører til på mere end ét sted og at ingen steder permanent er det privilegerede sted. Hvorfor tilstedeværelsen dér hvor man aktuelter, er en fornyet mulighed for altid at kunne etablere kommunikation og at kunne gentage den og forny den. Uden at behøve et komplet defineret sted, en total historie, eller en gennemtænkt intentionalitet. Den inoderne by er mulighedsbetingelse for denne skiftende kommunikative kontekstualisering på mange niveauer - kropsligt, spatialt, elektronisk osv. Tværtimod at gøre kommunikationen abstrakt viser den tilbage til Czarnowskis første punkt: den kropslige tilstedeværelse er grundlaget for den rumlige forankring. På den ene side en æstetiserende individualisering af stedet, på den anden side en forpligtelse på dets umiddelbare materielle og erfaringsbårne tilgængelighed. De mange urbane, rastløse personer med kvalme i det 20. århundredes romaner er ikke nødvendigvis på jagt efter en identitet, en subjektivitet og en omverdenserfaring med umiddelbar gyldighed. De mangler den ikke. De har tværtimod for meget af den. De søger snarere en social sammenhæng at anbringe den i. Og det er vel den moderne bys største problem: ikke hvordan vi restituerer individet, men hvordan vi laver byen om fra en sum af individuelle steder til et socialt sted?

\section{Litteratur}

Andersen, Hans Christian (1899). Dryaden, Udvalgte Skrifter 8. København: Gyldendal. 135-163.

Anderson, Stanford (ed.) (1986). On Streets. Cambridge: MIT Press.

Aristoteles (1921). Politica. The Works of Aristotle translated into English 10. Oxford: Oxford University Press.

Auster, Paul (1990). The New York Trilogy. Harmondsworth: Penguin. Baggesen, Jens (1965). Labyrinten. København: Gyldendal.

Balzac, Honoré de (1965). Honorine. La Comédie humaine 1. Paris: le Seuil. Balzac, Honoré de (1966a). Les illusions perdues. La Comédie humanie 3. Paris: le Seuil.

Balzac, Honoré de (1966b). La cousine Bette. La Comédie humaine 5. Paris: le. Seuil.

Bellow, Saul (1964). Herzog. Greenwich, Conn.: Fawcett Crest.

Benjamin, Walter (1980). Charles Baudelaire. Frankfurt a.M.: Suhrkamp.

Benjamin, Walter (1987). Berliner Kindheit um neunzehnhundert. Frankfurt a.M.: Suhrkamp.

Brill, Michael (1989). Transformations, Nostalgia, and Illusion in Public life and Public Place. Irwin Altman og Ervin Zube (eds.). Public Spaces and Places. New York: Plenum. 7-29.

Burnham, Daniel og Edward Bennett (1970). Plan of Chicago. New York: Da Capo.

Campe, Joachim Heinrich (1790). Briefe aus Paris zur Zeit der Revolution. Braunschweig: Schulbuchhandlung.

Cauquelin, Anne (1986). Essais de philosophie urbaine. Paris: Presses Universitaires de France.

Çelik, Zeynep, Diane Favro and Richard Ingersoll (eds.). Streets. Critical Perspectives on Public Space. Berkeley: University of California Press, 1994.

Conrad, Peter (1984). The Art of the City. Views and Versions of New York Oxford: Oxford University. Press.

Diable (1845-46). Le Diable à Paris 1-2. Paris: Hetzel.

Dickens, Charles (1963). Sketches by Boz. London: Oxford University Press.

Dos Passos, John (1975). Century's Ebb. New York: Gambit.

Dos Passos, John (1979). U.S.A. 1-3. New York: Signet.

Ellis, Edward Robb (1990). The Epic of New York City. New York: Old Town Books.

Ellul, Jacques (1970). The Meaning of the City. Grand Rapids: William Eerdman.

Fournel, Victor (1858). Ce qu'on voit dans les rues de Paris. Paris: Delahays. 
Francis, Mark (1989). Control as a Dimension of Public-Space Quality. Irwin Altman og Ervin Zube (eds.). Public Spaces and Places. New York: Plenum. 147-172.

Gareau, Joel (1991). Edge City. Life on the New Frontier. New York: Doubleday.

Geist, Johann Friederich (1982). Passagen. Ein Bautyp des 19. Jahrhunderts. München: Prestel

Gibson, William (1993). Neuromancer. London: HarperCollins.

Glaab, Charles og Theodore Brown (1983). A History of Urban America. New York: Macmillan.

Haüßermann, Hartmut og Walter Siebel (1985). Neue Urbanität. Frankfurt a.M.: Suhrkamp.

Hitzer, Hans (1971). Die Straße. München: Calloway.

Homberger, Eric (1994). The Historical Atlas of New York City. New York: Henry Holt.

Hugo, Victor (1973). Les Misérables 1-3: Paris: Gallimard.

Johnston, John (1984). The Poet and the City. A Study in Urban Perspectives. Athens: The University of Georgia Press.

Peter Jukes (ed.) (1991). A Shout in the Street. Berkeley: University of California Press.

Kostof, Spiro (1992). The City Assembled. London: Thames and Hudson. Krier, Rob (1978). Urban Space. London: Academy.

Larsen, Svend Erik (1985). By og litteratur. Rundt i landsbyrinten. Bidrag 19/20, Odense. 105-156.

Larsen, Svend Erik (1988). Lyrikken - skyklap eller brændglas. Annelise Ballegaard Petersen og Carsten Nicolaisen (eds.). Krystalgitteret. Den lyriske genres funktion. Odense: Odense Universitetsforlag. 39-66.

Larsen, Svend Erik (1989) „....et åndepust på spejlglas“. Om krop, identitet, fantasi og masse. Erik Svejgaard og John Thobo-Carlsen (eds.). Fantasi og fiktion. Odense: Odense Universitetsforlag. 271-312.

Larsen, Svend Erik (1990a). Fingerøvelser. Om krop, rum og tegn. Hans Hyllested, Niels Guttormsen og Jens Smærup Sørensen (eds.). Spor. Til billedet og poesien. Viborg: Arkiv for ny litteratur. 157-170.

Larsen, Svend Erik (1990b). Døgnets flaner. Flanøren som stereotype. Gunhild Agger, Barbara Gentikow og Ulf Hedetoft (eds.). Stereotyper $i$ Europa. Århus: Århus Universitetsforlag. 219-235.

Larsen, Svend Erik (1991a). Mallarmé: Modernista y modista. Poesía y periodismo en un contexto urbano. Lisa Block de Behar (ed.): Términos de comparación. Los estudios literarios entre historias y teorías. Montevideo: Academia Nacional de Letras. 133-148.

Larsen, Svend Erik (1991b). Bykultur som humanistisk studieobjekt. Kjell Lars Berge og Ulla-Britt Kotsinas (eds.). Storstadsspråk och Storstadskultur $i$ Norden. Stockholm: Stockholms Universitet. 10-22.

Larsen, Svend Erik (1991c). Urban Indices. Semiotica 86, 3/4. 289-304.
Larsen, Svend Erik (1992). Gadens rum - byens grænse. Frederik Stjernfelt og Anders Troelsen (eds.). Grænser, Århus: Århus Universitetsforlag. 104-132.

Larsen, Svend Erik (1993a). Har byen et naturligt rum? Lise Bek. Gregers Algreen-Ussing og Jens Schjerup Hansen (eds.). Syn for rum. Om byens.og landskabets æestetik. Århus: Århus Universitetsforlag. 70-80.

Larsen, Svend Erik (1993b). Contemplation and Distraction: A Visua Analysis of Two Urbanized Natural Sceneries.Thomas Møller Kristensen, Svend Erik Larsen, Per Grau Møller, Steen Estvad Pedersen (eds.) City and Nature, Changing Relations in Time and Space. Odense: Odense Universitetsforlag. 79-96.

Larsen, Svend Erik (1993c). La ville - objet perdu, objet créé. Joëlle Rét horé (ed.). Variations sur l'objet. En hommage à Gérard Deledalle (= Revue Européenne d'Études sémiotiques V, 1/2). Wien. 109-123.

Larsen, Svend Erik (1994a). Roads to Nature. Stipe Grgas og Svend Erik Larsen (eds.). The Construction of Nature. A Discursive Strategy in Modern European Thought. Odense: Odense Universitetsforlag. 87-104.

Larsen, Svend Erik (1994b). Déspatialisation et respatialisation. Pierre Pellegrino (ed.). Figures architecturales. Formes urbaines, Paris/Genève: Anthropos/Economica. 167-173.

Larsen, Svend Erik (1994c). Representation and Intersemiosis. Herman Parret (ed.). Peirce and Value Theory. Amsterdam: John Benjamins. 255276.

Larsen, Svend Erik (1994d). Et in Arcadia ego. A Spatial and Visual Analysis of the Urban Middle Space. Thomas A. Sebeok and Jean Umiker-Sebeok (eds.) Advances in Visual Semiotics (=The Semiotic Web 1992-1993). Berlin/New York: Mouton de Gruyter. 537-557.

Larsen, Svend Erik (1994e). Paris i litteraturen: Verdensspejl og gadespejl. Fransk Nyt 197, Juli 1994. Viborg. 2-20.

Larsen, Svend Erik (1995a). Benjamin, byen, Balzac. Kritik 114. 87-100.

Larsen, Svend Erik (1995b). The Other in the Crowd: An Urban Vision. Gerald Gillespie, Margeret R. Higonnet og Sumie Jones (eds.). Visions in History - Visions of the Other. The Force of Vision 2. Tokyo: Tokyo University Press. 531-538.

Larsen, Svend Erik (1996a). Between Nowhere and Everywhere: Literature and the City. Revue Canadienne de Littérature Comparée (i trykken).

Larsen, Svend Erik (1996b) La rue entre ville et nature. Annelise Ballegaard og Svend Erik Larsen (eds.). La Rue - espace ouvert, Odense Universitetsforlag/Presses Universitaires de Grenoble (i trykken).

Larsen, Svend Erik (1996c). Die natürlichen Zeichen der Stadt. Eine Analyse des Prospekt Parks. Svend Erik Larsen (ed.). Der Park als kultursemiotische Funktion (=Zeitschrift für Semiotik XVII, 2/3), Berlin (i trykken). Larsen, Svend Erik (1996d). Naturen er ligeglad. København: Rosinante (i trykken). 
Larsen, Svend Erik og Jørgen Dines Johansen (1994). Tegn i brug. København: Amanda/Dansklærerforeningen.

Larsen, Svend Erik og Annelise Ballegaard Petersen (eds.) (1996). La Rue - espace ouvert, Odense Universitetsforlag/Presses Universitaires de Grenoble (i trykken).

Mitchell, William (1995). City of Bits. Space, Place and the Infobahn. Cambridge: MIT Press.

Mumford, Lewis (1961). The City in History. Harmondsworth: Penguin.

Nielsen, Hans-Jørgen (1968). City by Night, City by Light. Nielsen og den hvide verden. København: Borgen. 107-111.

Nielsen, Hans-Jørgen (1985). Billeder på intetheden. Kritik 80. 34-58.

Norberg-Schultz, Christian (1984). Genius Loci. Towards a Phenomenology of Architecture. New York: Rizzoli.

Nye, David (1992). Electrifying America. Cambridge: MIT Press.

Olsen, Donald (1986). The City as a Work of Art. New Haven: Yale University Press.

Relph, Edward (1974). Place and Placelessness. London: Pion.

Rodenberg, Julius (ed.) (1867). Paris bei Sonnenschein und Lampenlicht. Leipzig: Brockhaus.

Sennett, Richard (1988). Palais Royal. Paris: Albin Michel.

Sorkin, Michael (ed.) (1992). Variations on a Theme Park. New York: Hill and Wang.

Trollope, Frances (1949). Domestic Manners of the Americans. New York: Knopf.

Trollope, Frances (1836). Paris and the Parisians in 1835 I-II. New York: Harper and Brothers.

Tuan, Yi-Fu (1977). Space and Place. Minnesota: University of Minnesota Press.

Whitfield, Peter (1994). The Image of the World. London: The British Library.

Whitman, Walt (1969). Mannahatta. American Literature. Tradition and Innovation 2. Lexington: Heath and Co. 1954-1955. 